\title{
Regeneration patterns of key pine species in a mixed-pine forest indicate a positive effect of variable retention harvesting and an increase in recruitment with time
}

Priscilla A. Nyamai ${ }^{1 *}$, P. Charles Goebel ${ }^{2}$, R. Gregory Corace $\| I^{3}$ and David M. Hix

\begin{abstract}
Background: Many fire-dependent forests have experienced significant declines in species, structural, and functional diversity. These changes are attributed in part to traditional management approaches that were dominated by even-aged regeneration methods such as clearcutting. Variable retention harvesting $(\mathrm{VRH})$ is an ecologically based forestry practice that involves retention of some mature overstory trees and other biological structures in the postharvest stand to emulate the effects of natural disturbance events. In this study, we examined the effect of a VRH treatment on recruitment of historically dominant pine species and understory vegetation twoand six years after its implementation in a naturally regenerated mixed pine forest in the Upper Peninsula of Michigan, USA.

Results: We found greater regeneration of red pine (Pinus resinosa L.) and eastern white pine (Pinus strobus L.) in VRH stands compared to the unharvested controls. Although red pine recruitment was very low during the first 2 years, both species increased significantly from year two to year six. Recruitment responses for the two species did not differ significantly between the aggregated and dispersed retention treatments. We also found high recruitment of deciduous tree species, consisting primarily of sprouts, and red pine exhibited a negative correlation with these sprouts. Treatment, time, and the interaction of treatment and time were significant factors in red pine recruitment. Time had a strong effect on the understory vegetation, with significant decreases in shrubs and ferns over time.

Conclusions: The results suggest that VRH enhanced recruitment of red pine and eastern white pine and that this recruitment increased with time. We identify competition from sprouts and unfavorable seedbed conditions as the main factors that limited recruitment of red pine during the first 2 years. To reduce competing vegetation and improve seedbed conditions, we suggest following the VRH with a prescribed fire, mechanically removing sprouts, and implementing herbicide treatments. At a time when changes in global climate exacerbates the effects of traditional drivers of forest degradation, and with the need to maintain biodiversity, new ecologically based forest practices such VRH have the potential to facilitate regeneration of native trees and enhance the resilience of many fire-dependent forests.
\end{abstract}

Keywords: Variable retention harvesting, Aggregated retention, Dispersed retention, Mixed-pine forest, Pinus resinosa, Pinus strobus

\footnotetext{
* Correspondence: nyamaip@gvsu.edu

${ }^{1}$ Natural Resources Management Program, Grand Valley State University, 1

Campus Dr, Allendale, MI 49401, USA

Full list of author information is available at the end of the article
}

\section{Springer Open}

(๑) The Author(s). 2020 Open Access This article is licensed under a Creative Commons Attribution 4.0 International License, which permits use, sharing, adaptation, distribution and reproduction in any medium or format, as long as you give appropriate credit to the original author(s) and the source, provide a link to the Creative Commons licence, and indicate if changes were made. The images or other third party material in this article are included in the article's Creative Commons licence, unless indicated otherwise in a credit line to the material. If material is not included in the article's Creative Commons licence and your intended use is not permitted by statutory regulation or exceeds the permitted use, you will need to obtain permission directly from the copyright holder. To view a copy of this licence, visit http://creativecommons.org/licenses/by/4.0/. 


\section{Background}

Changes in fire regimes, land use practices that replace forested areas with human structures, and forest management techniques that simplify forest ecosystems have adversely affected many pine-dominated forests in the Great Lakes region of the United States (Whitney 1987; Cleland et al. 2004; Drobyshev et al. 2008a). The adverse effects include shifts in plant species composition, inadequate regeneration of historically dominant pine species, structurally simplified stands, declines in wildlife habitat, and accumulation of fuels (Frelich 1995; Drobyshev et al. 2008b; Corace III et al. 2014; Nyamai et al. 2014). Traditional management practices in these forests have been based on models whose effects are not analogous to those of the natural disturbance processes that shaped their development (Seymour et al. 2002; Palik and D'Amato 2019). Clearcutting as one of these practices has been associated with impacts that simplify the structural and compositional complexity of a stand, resulting in reduced biodiversity, habitat functions, and ecological resilience of these forests among other things (Lindenmayer and Franklin 2002; Puettmann et al. 2009; Lindenmayer et al. 2012). As a result, new forest management practices that impact stands in ways that more closely emulate the effects of natural disturbance events have been adopted in many places (Franklin et al. 2007; Gustafsson et al. 2012; Lindenmayer et al. 2012; Fedrowitz et al. 2014; Puettmann et al. 2015; Palik and D'Amato 2019). Among these practices is "Retention forestry", a management approach that emphasizes creation of multiaged stands and retention of mature overstory trees in varying structural patterns to achieve various objectives (Franklin et al. 2007; Gustafsson et al. 2012; Lindenmayer et al. 2012; Fedrowitz et al. 2014; Mori and Kitagawa 2014).

The more widely adopted retention forestry practice is variable retention harvesting (VRH). VRH is defined in Helms (1998) as "an approach to harvesting based on the retention of structural elements or biological legacies from the harvested stand for integration into the new stand to achieve various ecological objectives". Implementation of VRH involves retention of some mature overstory trees and other biological structures in various structural patterns during harvesting operations to achieve specific management objectives (Franklin et al. 2007; Palik and D'Amato 2019). The three key characteristics of VRH are 1) what is retained, 2) how much is retained, and 3) the spatial pattern of retention. Pattern of retention refers to the spatial distribution of retained structures, which can be either aggregated or dispersed. Aggregated retention comprises a mosaic of open patches where nearly all trees are removed, and patches where trees are retained in clusters. In dispersed retention, the retained trees are uniformly distributed across the stand. This variation in pattern of retained structures is thought to provide opportunities to emulate various structural features created in stands by different types and intensities of natural disturbance events (Franklin et al. 2007).

VRH has been applied in and effects on various forest components studied across the Great Lakes region (Bebber et al. 2005; Peck et al. 2012; Roberts et al. 2016, 2017), in other parts of the United States (Battaglia et al. 2002; Aubrey et al. 2009; Franklin and Donato 2020), and across the globe (Mori and Kitagawa 2014; Beese et al. 2019; Scott et al. 2019). Within the northern Lake States region, majority of these studies have been conducted in forests that in the past were managed using even-aged regeneration methods such as clearcutting, followed by planting pine seedlings (Palik and D'Amato 2019). To expand our knowledge and inform management, there is need to examine the effectiveness of VRH in restoring key species in naturally regenerated forests that have not been clearcut or planted since historical logging by EuroAmerican settlers. Additionally, given its documented benefits (Lindenmayer et al. 2012; Fedrowitz et al. 2014), including potential to enhance the resilience of forest ecosystems to the impacts of climate change (Nagel et al. 2017), information on the viability of VRH in diverse ecosystem types would be beneficial to its expansion to other geographical and management contexts. To address these needs, we conducted an experimental study that examined the effect of VRH on recruitment of key species in a naturally regenerated mixed pine forest in the eastern Upper Peninsula of Michigan, USA.

The VRH in our study area was implemented as a restoration application to promote recruitment of red pine (Pinus resinosa L.) and eastern white pine (Pinus strobus L.). The two pine species were targeted because they are the historically dominant species in these mixed-pine forests under unaltered conditions. A secondary objective was to reduce jack pine (Pinus banksiana Lamb.) and broadleaved tree species that had increased in abundance in these stands, contributing flammable material and creating hazardous fire conditions (Drobyshev et al. 2008b). The VRH created both aggregated and dispersed retention patterns in the harvested stands. We sought to answer the following questions: 1) what is the effect of VRH on recruitment of red pine, eastern white pine, and other vegetation two- and six years following application, and does this effect differ by pattern of retention? 2) how does recruitment change between year two and year six following the harvest? We examined responses using the two time periods because they represent a gradation of site conditions and competitive interactions following disturbance, which may impact tree recruitment differently. Examining recruitment over time also allows us to examine potential trends in recruitment of the two target species, particularly given that red pine is often difficult to regenerate in many areas (Ahlgren 1976; 
Godman and Mattson 1976). We hypothesized that there would be greater recruitment of red pine and eastern white pine in the VRH stands compared to the unharvested control stands due to increased availability of resources including greater light penetration into the understory and decreased competition since the stand density would be reduced. We also hypothesized that recruitment would be greater in the initial years (e.g., during the first year or two) because the newly altered overstory and forest floor conditions are likely to be more favorable for recruitment of the two pine species during this initial phase of recolonization. Finally, we hypothesized that the effects of VRH on recruitment would differ between the two retention patterns because of the variation in stand structure created by the two retention treatments.

\section{Methods}

\section{Study area}

The study was conducted at the Seney National Wildlife Refuge (SNWR), located in the Upper Peninsula of Michigan, USA (46.271594 $\left.\mathrm{N}, 86.057078^{\circ} \mathrm{W}\right)$. SNWR lies within the Seney Lake Plain ecoregion and is characterized by soils and physiographic features shaped by postglacial erosion and soil formation processes (Albert 1995). All the stands included in this study were on soils ranging from well to excessively drained coarse sands. Temperatures vary between an average minimum of $13^{\circ} \mathrm{C}$ in the coldest month and $27^{\circ} \mathrm{C}$ in the warmest month, average annual precipitation is $78 \mathrm{~cm}$, and growing season averages about 119 days (MRCC 2020). The stands were also within the eastern white pine/blueberry (Vaccinium)/trailing arbutus (Epigaea repens) habitat type as described by Burger and Kotar (2003). Presettlement mixed-pine forest ecosystems were dominated by red pine and eastern white pine, with minor components of jack pine and a variety of deciduous species (Whitney 1987). Current stands have been significantly altered, having a large component of jack pine and deciduous species in many areas. These altered naturally regenerated stands, coupled with available information on stand structure, composition and disturbance history from prior studies within SNWR (Drobyshev et al. 2008a, b; Corace III et al. 2013; Nyamai et al. 2014) makes the study area a good model system to test emerging restoration and management techniques such as VRH.

\section{Harvest treatments and field methods}

The study was conducted within nine stands ranging in size from 3.2 to 6.4 ha. Selected stands were randomly assigned to treatments, with three receiving the aggregated retention, three receiving the dispersed retention, and three unharvested controls. For the aggregated retention, overstory basal area was reduced by creating within the stand a mosaic of completely open patches $(\sim 0.3 \mathrm{ha})$ and patches with trees retained in clusters (Fig. 1). For the dispersed retention, overstory basal area was reduced by leaving retained trees uniformly dispersed across the stand (Fig. 1). Both treatments targeted $30 \%$ retention of the initial overstory basal area in each stand (which is $\sim 22 \mathrm{~m}^{2}$ per ha). We used unharvested stands for controls instead of clearcuts because the focus of this study was to understand what happens when VRH is implemented in current degraded stands compared to when nothing is done and stands left as they are. Additionally, clearcutting is not a practice conducted in our study system since it is a national wildlife refuge where more ecologically based management approaches are required. Other studies have also used unharvested stands as controls (e.g., Halpern et al. 2005; Roberts et al. 2016, 2017; Lindenmayer et al. 2019).

Deciduous trees and jack pine were primarily targeted for removal, although in very few cases some red pine trees were removed to achieve the retention target. Additionally, all subcanopy stems including saplings of species targeted for removal were taken out. As a result, retained overstory trees in the VRH stands primarily consisted of red pine, eastern white, and any snags of all tree species. Logging was conducted during the growing
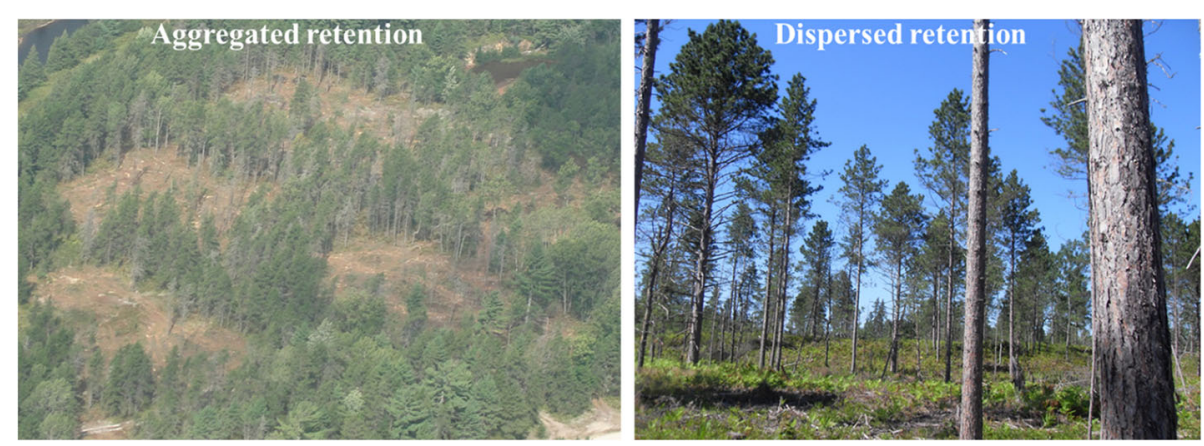

Fig. 1 Aggregated and dispersed retention patterns created during the VRH in a mixed-pine forest ecosystem in the eastern Upper Peninsula of Michigan, USA 
season and a "timber processor" with a mechanized head on an extendable boom was used. Trees were delimbed to approximately $2.6 \mathrm{~m}$ and removed from the stands with a forwarder. All equipment used had tires and not tracks. The cut trees were de-limbed on site, merchantable boles taken out, and the smaller-size woody debris and slash were left on site and spread across the ground surface.

Within each stand, we established a network of six 25$\mathrm{m}^{2}$ ( $5 \mathrm{~m}$ by $5 \mathrm{~m}$ ) plots that we used to collect data on tree seedlings and cover of herbs, shrubs, and ferns. Since the aggregated retention consists of both open patches and patches with tree clusters, plots in these stands were established by assigning three plots in the open patches and three within the tree clusters. Although edge effects can be an important factor in the aggregated retention (Powers et al. 2008; Franklin et al. 2018), our objective was to capture responses that represent the average conditions of both the open and retained tree patches represented in the aggregated treatment. To establish plots, we established a grid system over each stand in ArcGIS 10.1 (2012) and generated several grid intersections. We then randomly selected six grid intersections that served as centers of six replicate study plots in each stand. The result was a total of 54 plots in this study ( $n=18$ in aggregated, $n=$ 18 in dispersed, and $n=18$ in control). Within each plot, we recorded count of all tree seedlings (stems $<2.5 \mathrm{~cm}$ $\mathrm{dbh}$ ). For deciduous species that exhibited sprouting, each individual stem was counted separately. To discriminate between seedlings recruited pre- and posttreatment, we estimated the age of tree seedlings by counting number of whorls for pine species, and number of terminal bud scars for deciduous species. The stands did not appear to have much advance regeneration based on visual assessments, and nearly all the seedlings recorded were younger than 2 years at the time of initial sampling, based on our age estimation. We also estimated the percent cover of herbs, shrubs, and ferns. Taxonomic authority used in plant identification followed the PLANTS database (USDA NRCS 2014).

\section{Statistical analyses}

To prepare data for analysis, we summarized seedling and cover data by plot. We then examined differences between treatments using Analysis of Variance (ANOVA) in SAS (SAS v. 9.4 SAS Institute, Cary, NC) and conducted pairwise comparisons of these treatments using Tukey's HSD post-hoc test. ANOVA was conducted on the data for each time periods individually, then on the combined data of both time periods to examine treatment and time interactions. Understory vegetation particularly shrubs in the Ericaceae family have been found to influence recruitment of pine trees (Roberts et al. 2016, 2017). We were thus interested in how these understory species might influence red pine and eastern white pine recruitment in the VRH stands. To examine that, we conducted a Canonical Correspondence Analysis (CCA) using CANOCO v. 5.12 (Braak and Smilauer, Ithaca, NY, USA). CCA is a direct gradient ordination analysis used to examine how measured predictor variables drive patterns of species occurrence and distribution in space. We used the data for herbs, shrubs, ferns, red maple (Acer rubrum L.), northern red oak (Quercus rubra L.) and aspen (Populus spp.) as predictor variables for the occurrence of red pine and eastern white pine. Red maple, northern red oak, and aspen were included as predictors because of their abundance based on the seedling density data. The effect of predictor variables on the response variables was tested using an unrestricted random Monte Carlo permutation test with 999 permutations and the default linear combination (LC) site scores.

\section{Results}

\section{Tree seedling densities}

Two years after treatment, recruitment of red pine was low overall, with seedlings observed only in the dispersed retention (104 seedlings.ha ${ }^{-1}$ ) and no treatment effect $\left(F_{2,51}=1.89, P=0.162\right.$; Fig. 2, Table 1$)$. Compared to red pine, we found higher density of eastern white pine seedlings and significant treatment effects $\left(F_{2,51}=\right.$ $3.51, P=0.037)$ in year two. There were 659 seedlings.ha ${ }^{-1}$ in the aggregated retention, 763 seedlings $\cdot \mathrm{ha}^{-1}$ in the dispersed retention, and 138 seedlings.ha ${ }^{-1}$ in the control (Table 1). These densities only differed significantly $(P=0.043)$ between the dispersed retention and the control in year two, with no significant difference between the two retention treatments $(P=0.911$; Fig. 2$)$. After 6 years, both red pine and eastern white pine had increased significantly in the VRH stands (Fig. 2, Table 1). Unlike year two, there was significant treatment effects for red pine in year six $\left(F_{2,51}=4.76, P=0.013\right)$, the highest seedling density was found in the aggregated retention (312 seedlings.ha ${ }^{-1}$ ), the density in the dispersed retention doubled (208 seedlings.ha ${ }^{-1}$ ), and there was still no recruitment in the control stands (Fig. 2, Table 1). As was in year two, recruitment did not differ significantly between the two retention treatments in year six $(P=0.57)$. We also found significant treatment effects for eastern white pine in year six $\left(F_{2,51}=5.20, P=0.008\right)$, with recruitment only differing significantly between the aggregated retention and the control $(P=0.007)$ but not between the two retention treatments $(P=0.636$; Fig. 2$)$. Similar to red pine in year six, the highest seedling density for eastern white pine was found in the aggregated retention (1180 seedlings.ha ${ }^{-1}$ ) with the least recruitment in control stands (104 seedlings.ha ${ }^{-1}$; recruitment actually declined in year six in these stands (Table 1). Among the other 


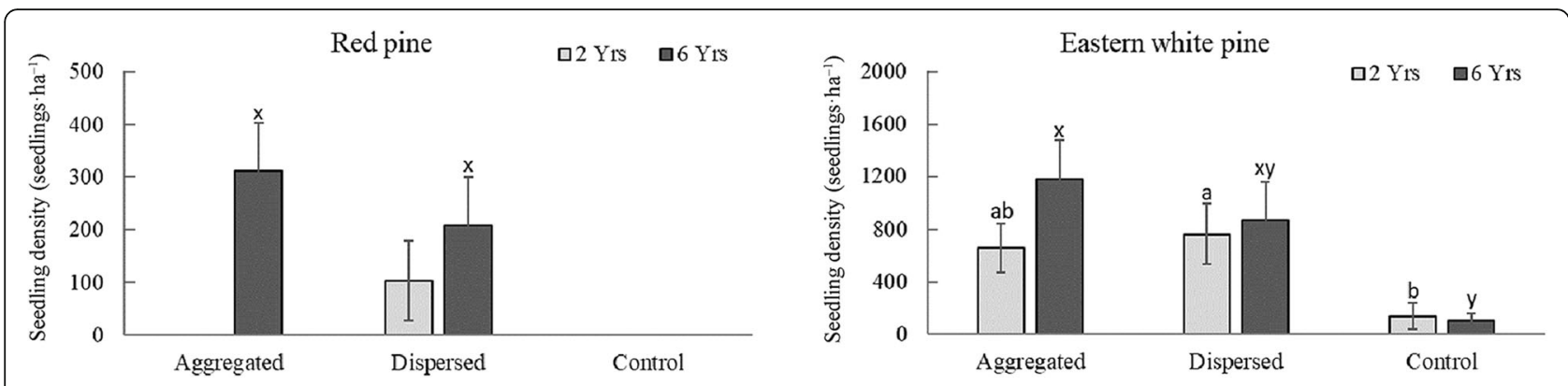

Fig. 2 Comparison of red pine and eastern white pine seedling density (seedlings.ha ${ }^{-1}$ ) among treatments 2 and 6 years since VRH treatment in a mixed-pine forest ecosystem in the eastern Upper Peninsula of Michigan, USA. Letters a and b are used to indicate significant differences among treatments for the 2 year data, while letters $x$ and $y$ are used to indicate significant differences among treatments for the 6 year data $(P<0.05)$

tree species, red maple exhibited the most recruitment in VRH stands in both time periods, with highest density in the aggregated retention (Table 1 ) in both years, and significant treatment effects in year two $\left(F_{2,51}=5.39, P=\right.$ $0.007)$ and year six $\left(F_{2,51}=4.55, P=0.015\right)$. Recruitment for red maple differed significantly between the two retention treatments in year two $(P=0.02)$ but not in year six $(P=0.086)$ and increased between the 2 years (Table 1). Northern red oak and aspen showed similar trends of high recruitment in VRH stands and increases in recruitment with time since harvest (Table 1). When the two time periods were considered together, both treatment and time were significant factors in red pine recruitment with time having a stronger effect, and a significant time by treatment interaction (Table 2). Conversely, treatment was the only significant factor in eastern white pine recruitment (Table 2). Red maple, northern red oak, and aspen were all strongly affected by both treatment and time, although the interaction between these two factors was not significant for these species (Table 2).

\section{Cover of shrubs, herbs, and ferns}

For the understory vegetation, lowbush blueberry (Vaccinium angustifolium Aiton) and velvet-leaf blueberry

Table 1 Mean ( \pm 1SE) seedling density (seedlings.ha ${ }^{-1}$ ) by retention treatment for tree species documented in a mixed-pine forest ecosystem in the eastern Upper Peninsula of Michigan, USA

\begin{tabular}{|c|c|c|c|c|}
\hline \multirow[t]{2}{*}{ Species common name } & \multirow[t]{2}{*}{ Species scientific name } & \multicolumn{3}{|c|}{ Mean seedling density ( \pm 1SE) (seedlings:ha ${ }^{-1}$ ) } \\
\hline & & Aggregated & Dispersed & Control \\
\hline \multicolumn{5}{|l|}{2 years since treatment } \\
\hline Red pine & Pinus resinosa $\mathrm{L}$. & $0 \mathrm{a}$ & $104 \pm 76 a$ & $0 \mathrm{a}$ \\
\hline Eastern white pine & Pinus strobus L. & $659 \pm 185 a b$ & $763 \pm 229 a$ & $138 \pm 95 b$ \\
\hline Jack pine & Pinus banksiana Lamb. & $0 \mathrm{a}$ & $0 \mathrm{a}$ & $0 \mathrm{a}$ \\
\hline Red maple & Acer rubrum L. & $6840 \pm 1895 a$ & $2395 \pm 420 b$ & $1979 \pm 515 b$ \\
\hline Northern red oak & Quercus rubra L. & $1076 \pm 230 \mathrm{a}$ & $1631 \pm 375 a$ & $659 \pm 274 a$ \\
\hline Aspen (quaking \& bigtooth) & Populus spp. & $1215 \pm 430 a$ & $3715 \pm 941 b$ & $69 \pm 69 a$ \\
\hline Balsam fir & Abies balsamea (L.) Mill. & $243 \pm 430 \mathrm{a}$ & $0 \mathrm{a}$ & $486 \pm 450$ a \\
\hline Black spruce & Picea mariana (Mill.) & $0 \mathrm{a}$ & $0 \mathrm{a}$ & $381 \pm 203 a$ \\
\hline \multicolumn{5}{|l|}{6 years since treatment } \\
\hline Red pine & Pinus resinosa $\mathrm{L}$. & $312 \pm 91 a$ & $208 \pm 91 \mathrm{ab}$ & $0 \mathrm{~b}$ \\
\hline Eastern white pine & Pinus strobus L. & $1180 \pm 298$ a & $868 \pm 290 a b$ & $104 \pm 56 b$ \\
\hline Jack pine & Pinus banksiana Lamb. & $138 \pm 80 a$ & $138 \pm 80 a$ & $0 \mathrm{a}$ \\
\hline Red maple & Acer rubrum L. & $10,833 \pm 2452 a$ & $5381 \pm 1600 \mathrm{ab}$ & $3541 \pm 954 b$ \\
\hline Northern red oak & Quercus rubra L. & $2569 \pm 410 a$ & $2638 \pm 636 a$ & $1388 \pm 557 a$ \\
\hline Aspen (quaking \& bigtooth) & Populus spp. & $5590 \pm 1372 \mathrm{a}$ & $4756 \pm 1151 \mathrm{a}$ & $2222 \pm 753 a$ \\
\hline Balsam fir & Abies balsamea (L.) Mill. & $833 \pm 429 a$ & $0 \mathrm{a}$ & $416 \pm 350$ a \\
\hline Black spruce & Picea mariana (Mill.) & $0 \mathrm{a}$ & $69 \pm 47 a$ & $798 \pm 306$ b \\
\hline
\end{tabular}


Table 2 ANOVA results showing the effects of treatment, time, and the interaction of treatment and time on the inventoried vegetation in a mixed-pine forest ecosystem in the eastern Upper Peninsula of Michigan, USA

\begin{tabular}{|c|c|c|c|c|}
\hline Vegetation & Treatment & Time & Treatment $\times$ Time & Retention comparisons \\
\hline Red pine & $F=4.5, P=0.01$ & $F=8.0, P=0.005$ & $F=3.5, P=0.03$ & $P=0.96$ \\
\hline Eastern white pine & $F=8.3, P=0.0004$ & $F=1.27, P=0.26$ & $F=0.9, P=0.40$ & $P=0.87$ \\
\hline Jack pine & $F=1.4, P=0.23$ & $F=5.9, P=0.02$ & $F=1.4, P=0.23$ & $P=0.99$ \\
\hline Red maple & $F=9.3, P=0.0002$ & $F=5.4, P=0.02$ & $F=0.3, P=0.71$ & $P=0.004$ \\
\hline Northern red oak & $F=3.4, P=0.04$ & $F=9.0, P=0.003$ & $F=0.4, P=0.68$ & $P=0.76$ \\
\hline Aspen (quaking \& bigtooth) & $F=6.3, P=0.003$ & $F=11.8, P=0.0008$ & $F=1.8, P=0.17$ & $P=0.62$ \\
\hline Balsam fir & $F=1.8, P=0.17$ & $F=0.5, P=0.49$ & $F=0.7, P=0.49$ & $P=0.18$ \\
\hline Black spruce & $F=9.6, P=0.0001$ & $F=1.8, P=0.19$ & $F=1.1, P=0.34$ & $P=0.97$ \\
\hline Shrubs & $F=0.2, P=0.82$ & $F=133.4, P<0.001$ & $F=0.6, P=0.57$ & $P=0.81$ \\
\hline Herbs & $F=2.5, P=0.08$ & $F=75.7, P<0.001$ & $F=3.9, P=0.02$ & $P=0.32$ \\
\hline Ferns & $F=3.2, P=0.04$ & $F=173.3, P<0.001$ & $F=2.3, P=0.10$ & $P=0.09$ \\
\hline
\end{tabular}

(Vaccinium myrtilloides Michx.) dominated the shrub layer, while bracken fern (Pteridium aquilinum (L.) Kuhn) was most common in the herbaceous layer (Table 3). VRH did not appear to have a significant effect on shrub recruitment in the initial periods following harvest $\left(F_{2,51}=0.37, P=0.69\right)$, but there was a treatment effect after 6 years $\left(F_{2,51}=7.67, P=0.001\right.$; Fig. 3$)$. Shrub cover decreased an average of $78 \%$ in VRH stands between the two time periods. Herbaceous vegetation response was nearly opposite that of shrubs. There were significant treatment effects on herbaceous vegetation after 2 years $\left(F_{2,51}=3.76, P=0.03\right)$, but the difference was only between the aggregated retention and the control $(P=0.04 ;$ Fig. 3$)$. Although there was an average of $65 \%$ increase in herbaceous vegetation from year two to year six in VRH stands, there was no treatment effect for year six $\left(F_{2,51}=\right.$ 1.02, $P=0.36$; Fig. 3). Bracken fern exhibited similar patterns to those of the shrubs; there were no treatment effects after 2 years $\left(F_{2,51}=2.73, P=0.07\right)$, but there were treatment effects in year six $\left(F_{2,51}=5.42, P=0.007\right)$, with the cover differing only between the dispersed retention and the control $(P=0.006$; Fig. 3$)$. There was an average of $86 \%$ decrease in the cover of ferns in VRH stands between the two periods. When the two time periods were considered together, treatment had a significant influence on ferns only, time had a very strong influence on all three vegetation groups, and the interaction between treatment and time was a significant factor only for herbaceous vegetation (Table 2).

\section{Influence of other vegetation on red pine and eastern white pine recruitment}

CCA analyses revealed significant patterns of species occurrences along gradients associated with the predictor variables for both the two-year $(F=5.6, P=0.001)$ and the sixyear $(F=3.8, P=0.001)$ time periods. The four canonical axes for the two-year data accounted for $42 \%$ of the variation in the species composition data, while that of the six-year data accounted for $33 \%$. Two years after VRH, red pine seedlings exhibited a strong positive correlation with the first gradient (score $=0.42$; Fig. 4). Along this gradient, red pine seedlings were high in areas with high shrub cover but low cover of herbs and ferns, as well as low densities of maple, oak, and aspen seedlings (Fig. 4, Table 4). Eastern white pine on the other hand had a strong positive

Table 3 Shrub, herb, and fern species documented in study plots in a mixed-pine forest ecosystem in the eastern Upper Peninsula of Michigan, USA

\begin{tabular}{ll}
\hline Shrubs & Scientific name \\
\hline Lowbush blueberry & Vaccinium angustifolium Aiton \\
Velvet-leaf blueberry & Vaccinium myrtilloides Michx. \\
Wintergreen & Gaultheria procumbens L. \\
Black huckleberry & Gaylussacia baccata (Wangenh.) K. Koch \\
Sand cherry & Prunus pumila L. \\
Sweetfern & Comptonia peregrina (L.) J.M. Coult. \\
Bush honeysuckle & Diervilla lonicera Mill. \\
Trailing arbutus & Epigaea repens L. \\
Running serviceberry & Amelanchier stolonifera Wiegand \\
Downy serviceberry & Amelanchier arborea (Michx. f.) Fernald \\
Labrador tea & Ledum groenlandicum Oeder \\
Leatherleaf & Chamaedaphne calyculata (L.) Moench
\end{tabular}

\section{Herbs}

Bunchberry dogwood Cornus canadensis L.

Starflower

Canada mayflower

Cowwheat

Trientalis borealis Raf.

Sheep sorrel

Maianthemum canadense Desf.

Melampyrum lineare Desr.

Rumex acetosella $\mathrm{L}$.

Ferns

Bracken fern Pteridium aquilinum (L.) Kuhn 

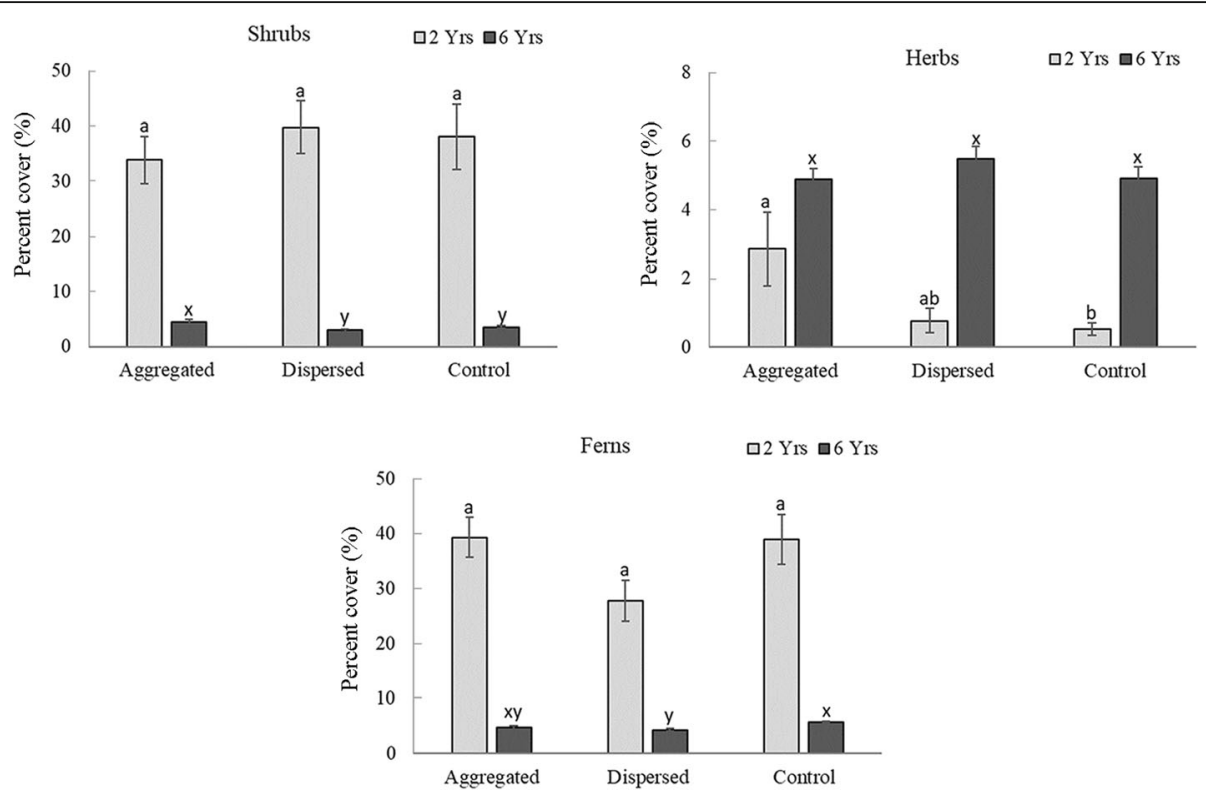

Fig. 3 Comparison of the percent cover of shrubs, herbs, and ferns among treatments 2 and 6 years since VRH treatment in a mixed-pine forest ecosystem in the eastern Upper Peninsula of Michigan, USA. Letters $a$ and $b$ are used to indicate significant differences among treatments for the 2 year data, while letters $x$ and $y$ are used to indicate significant differences among treatments for the 6 year data $(P<0.05)$

association with the second gradient (score $=0.45$, with high seedling density in areas with aspen but with low density and cover of all the other species (Fig. 4, Table 4). During the first 2 years, shrubs, ferns, oak, and maple exerted significant influence on recruitment of red pine and eastern white pine, while aspen and herbs did not have significant effects (Table 4). In contrast to responses in the first 2 years, red pine had a strong negative correlation with the first gradient after 6 years $($ score $=-0.56$; Fig. 4), with high density in areas of high herbaceous cover but low densities of maple, oak, and aspen seedlings (Fig. 4, Table 4). Eastern white pine exhibited a marginal positive association (score $=0.12$ ) with the first gradient and a moderate positive association (score $=0.27$ ) with the second gradient (Fig. 4) in this time period. Most of the eastern white pine seedlings were positively associated with the other cooccurring tree species including maple, oak and aspen (Fig. 4, Table 4). Only maple, oak, and ferns exerted
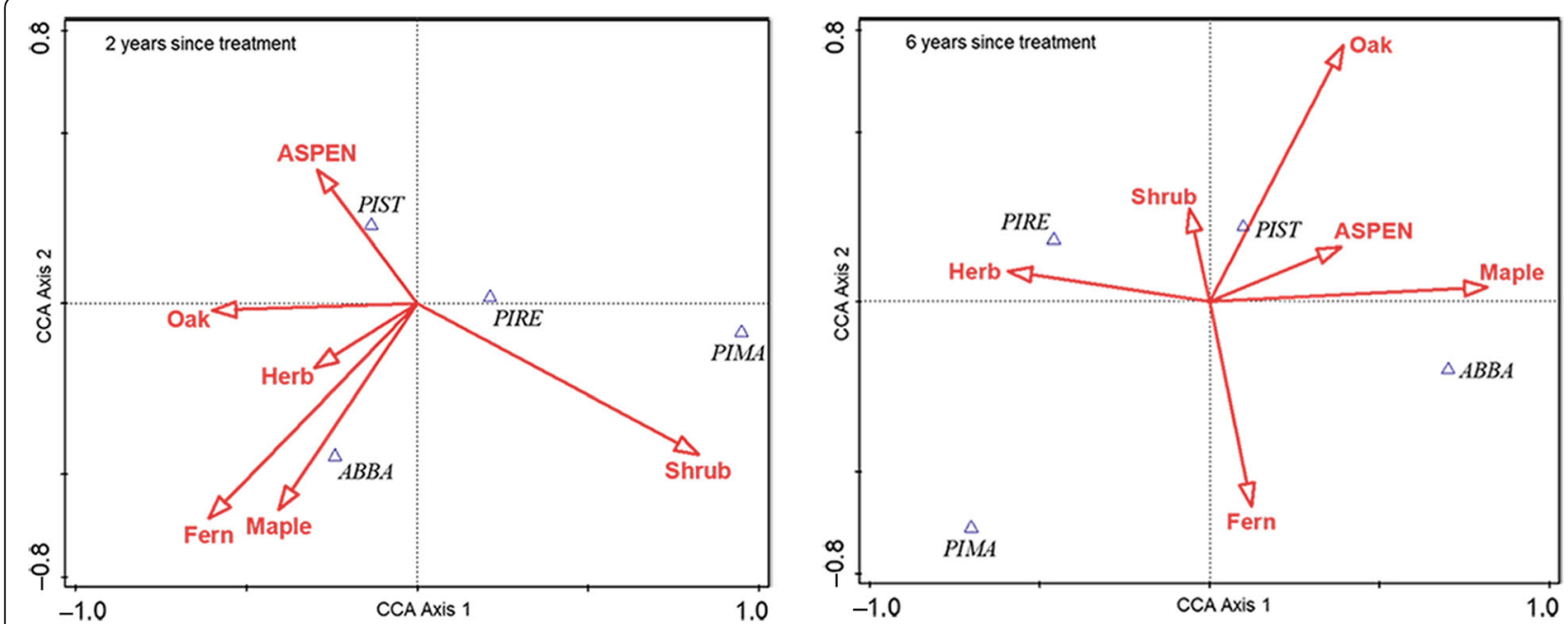

Fig. 4 CCA biplot showing the relationship between predictor variables (associated with arrows) on the occurrence and distribution of tree species (associated with triangles) in a mixed-pine forest ecosystem in the eastern Upper Peninsula of Michigan, USA. The tree species include $\mathrm{PIRE}=$ Red pine, PIST = Eastern white pine, $\mathrm{ABBA}=$ Balsam fir, and PIMA = Black spruce 
Table 4 CCA output for predictor variables in a mixed-pine forest ecosystem in the eastern Upper Peninsula of Michigan, USA. VIF= Variance Inflation factor (VIF). Correlation values are Pearson's Correlation Coefficient ( $r$ )

\begin{tabular}{|c|c|c|c|c|c|c|}
\hline Predictor variable & $F$ & $P$ & Variation explained & Correlation with Axis 1 & Correlation with Axis 2 & $\mathrm{VIF}$ \\
\hline \multicolumn{7}{|c|}{2 years since treatment } \\
\hline Shrubs & 12.8 & 0.001 & $19.8 \%$ & 0.65 & -0.27 & 1.3 \\
\hline Ferns & 9.3 & 0.001 & $15.2 \%$ & -0.48 & -0.38 & 1.8 \\
\hline Oak & 5.8 & 0.003 & $10.1 \%$ & -0.47 & -0.01 & 1.2 \\
\hline Maple & 5.4 & 0.040 & $9.4 \%$ & -0.32 & -0.36 & 3.2 \\
\hline Aspen & 2.4 & 0.095 & $4.4 \%$ & -0.23 & 0.24 & 1.1 \\
\hline Herbs & 1.7 & 0.156 & $3.1 \%$ & -0.24 & -0.12 & 2.4 \\
\hline \multicolumn{7}{|c|}{6 years since treatment } \\
\hline Maple & 7.7 & 0.002 & $12.9 \%$ & 0.61 & 0.02 & 1.3 \\
\hline Oak & 5.0 & 0.003 & $8.7 \%$ & 0.29 & 0.42 & 1.2 \\
\hline Herbs & 4.4 & 0.004 & $7.9 \%$ & -0.44 & 0.05 & 1.1 \\
\hline Ferns & 2.5 & 0.057 & $4.6 \%$ & 0.09 & -0.33 & 1.1 \\
\hline Aspen & 1.7 & 0.135 & $3.2 \%$ & 0.29 & 0.09 & 1.2 \\
\hline Shrubs & 1.2 & 0.300 & $2.3 \%$ & -0.04 & 0.15 & 1.1 \\
\hline
\end{tabular}

significant influence on the recruitment of red pine and eastern white pine in year six (Table 4).

\section{Discussion}

\section{VRH effects on recruitment}

When used for regeneration purposes, the application of VRH is typically based on the premise that by altering the structure of the overstory, the understory resource environment is likely to be affected in ways that favor recruitment and establishment of desired tree species. Our findings suggest that VRH can promote recruitment of restoration target species, in our case red pine and eastern white pine. Further, our findings indicate a significant time and interactive treatment by time effects for red pine, with greater recruitment over time seemingly driven by opportunistic resource availability. Given the silvical characteristics of red pine and eastern white pine, we attribute the responses observed in this study to several factors as discussed below.

\section{Dynamics of resource competition}

Following VRH operations, greater survival and growth of planted pine seedlings have been attributed to increases in resource availability (Boyden et al. 2012; Peck et al. 2012; Montgomery et al. 2013). We, therefore, anticipated that the structural changes brought about by the VRH at our study site would create conditions that would promote recruitment of both red pine and eastern white pine (Ahlgren 1976; Carey 1993). Our findings, however, show that red pine exhibited very low regeneration in VRH stands during the first two years but increased significantly by the sixth year, contrary to our hypothesis. In contrast, eastern white pine showed better recruitment in the VRH stands in both years, also increasing substantially from year two to year six. We suggest that the recruitment patterns observed for the two species was primarily driven by competition and believe that the contrasts in responses observed between red pine and eastern white pine are likely consistent with their differences in sensitivity to competition and substrate requirements for germination (Ahlgren 1976; Carey 1993).

The primary source of this competition for resources is likely recruited seedlings of deciduous species such as red maple, northern red oak, and aspen (Abrams 1998; Fei and Steiner 2009). We attribute the massive recruitment of these deciduous species to resprouting, and believe that it was disturbance mediated, likely by the VRH. It is likely that the sprouts exerted significant pressure on resources during the initial years, placing red pine at a greater competitive disadvantage (Dietrich et al. 2017). Ordination analysis also revealed significant negative influence of oak and maple on red pine, which supports the suggested impact of these species on red pine recruitment. Although eastern white pine increased significantly in VRH stands between year two and year six, its density was higher in VRH stands in both time periods relative to those of red pine, suggesting that competition was not as significant a factor in its recruitment as it was for red pine (Ahlgren 1976). The poor recruitment of the two pine species in the control stands coupled with increases in recruitment of competitor deciduous species over time may also be informative from a management perspective. They suggest the potential for significant and possibly irreversible alterations in species composition and stand structure in these forests if no restoration interventions are implemented. 
We found a strong effect of time and a significant interaction of treatment and time on red pine recruitment, while treatment was the only significant factor in eastern white pine recruitment. Both pine species also increased substantially between year two and year six. These findings suggest that although VRH enhanced recruitment of both pine species, these effects varied over the six-year duration, particularly for red pine. The new cohort of competing species discussed not previously as it is now may have exerted such intense pressure for resources during the initial years, that only a few individuals of red pine were able to survive in the competitive microsite conditions. Although this resource pressure appears to have persisted given the concurrent increases in recruitment of competitor species, we think that its effects were moderated over time by availability of recruitment opportunities. These opportunities may have been created for example by decreases in recruitment of understory vegetation, and/or as a result of decay of slash and other debris on the forest floor. The newly available space and nutrients likely supported additional red pine germination and establishment after the initial years. The potential for red pine to be more opportunistic for available resources long after the immediate period following disturbance as our findings suggests is an interesting finding given its restrictive site requirements (Hauser 2008). Besides competition by other tree species, it could be argued that advance regeneration in these stands can be an additional factor that could have had some effect on regeneration of the two pine species. Advance regeneration of deciduous species has been shown to respond to canopy gaps, making them more competitive for resources during the initial years (Reuling et al. 2019). We do not believe, however, that this was a significant factor in this study given the targeted reduction during harvest of unwanted advance regeneration.

We suggest some management recommendations for this, and similar mixed-pine ecosystems based on our discussion above regarding the dynamics of space and resource use between the pine and the deciduous species. When increasing natural regeneration of red pine is an objective, we recommend taking steps during or after the logging operation to limit resprouting of deciduous tree species. Prescribed fire that targets fire-intolerant competitors such as maple can be implemented following VRH treatments. Managers can also explore the possibility of mechanical removal of sprouts and/or herbicide treatment among other options. Since eastern white pine appears to do just fine with the VRH treatment based on our findings, the additional interventions we suggest here may not be as critical for eastern white pine as they are for red pine in cases where the primary objective is to regenerate eastern white pine.

\section{Effect of understory vegetation}

Understory vegetation in the herb and shrub layers can also be an important source of competition for naturally regenerating pine species. Retention harvests have been shown to influence recruitment and growth of understory vegetation (Halpern et al. 2012). By preempting resources, the understory vegetation can then place seedlings of woody species at a competitive disadvantage and limit treatment effects (Weyenberg et al. 2004; Montgomery et al. 2013; Roberts et al. 2017). We found no significant VRH effects on shrubs and ferns in year two, but the effects were significant in year six. Both shrubs and ferns decreased significantly in VRH stands between the two time periods, and only the herbaceous component increased. Ordination analysis revealed a strong positive association between red pine and shrubs in the initial years, but this spatial relationship changed by year six where red pine begins to associate more with the herbaceous vegetation. Eastern white pine on the other hand did well in areas with less shrubs in the initial years but the association became more positive by year six. The positive association between red pine and shrubs was contrary to our expectation that recruitment of both pine species would be limited in areas with high shrub cover (which was mostly blueberry). We had thought that the shrub component would be a source of resource competition, in addition to other potential inhibition mechanisms (Mallik 2003). We are not certain about the exact mechanism behind the positive relationship in the initial years for red pine. It could be that the shrubs provided some sort of refuge to newly germinated seedlings in the initial years, possibly just the right amount of shade from direct sunlight. Such a relationship would not be common or typical for an intolerant species like red pine though.

The effect of time was stronger for all three understory vegetation groups relative to the effect of treatment. Shrubs and ferns decreased by $78 \%$ and $86 \%$ respectively, while herbaceous vegetation increased by $65 \%$. We argue that decreases in shrubs and ferns likely contributed to the recruitment dynamics observed for red pine specifically. As described earlier, we think that these decreases potentially freed some resources that red pine then took advantage of. The strong effect of time also suggests that recruitment of shrubs and ferns may increase in the initial years after VRH but decreases over time. While we highlight this temporal aspect of VRH effects, we caution that any facilitative effects may not translate to significant recruitment impacts for the pine species if the sprouting of competing tree species is not addressed. We also note that there were no shrub reduction treatments before the VRH application in our study, as has been done in other studies within the region (Boyden et al. 2012; Peck et al. 2012; Montgomery et al. 2013; Roberts et al. 2017). 


\section{Seedbed requirements}

Compared to eastern white pine, red pine requires specific seedbed conditions, with more successful natural germination on exposed mineral soil, low duff and litter cover on the forest floor, and little competition from other vegetation (Ahlgren 1976; Ahlgren and Ahlgren 1981; Mallik and Roberts 1994). Low intensity surface fires typically create these conditions and facilitate natural recruitment of both red pine and eastern white pine in our study area (Drobyshev et al. 2008a; Nyamai et al. 2014). Mechanical scarification of the soil surface has also been used in other pine systems to promote successful seedling emergence and establishment (Landhäusser 2009). In this study, nearly all small-sized woody debris were left on site following the VRH. The reasoning at the time was that these materials would serve to provide habitat for other organisms and would break down over time. Although we did not examine the influence of litter on the forest floor, it is reasonable to think that this debris covering the ground surface likely contributed to the unfavorable seedbed conditions, possibly by inhibiting seed germination (Halpern and McKenzie 2001).

It has also been suggested that harvesting operations that do not significantly impact the forest floor to expose a mineral soil seedbed can provide a competitive advantage to other species that regenerate from root suckers and stump sprouts (Wiensczyk et al. 2011; D'Amato et al. 2012). We suspect that the VRH implemented in this case did not impact the seedbed enough to create adequate conditions favorable for red pine germination, and instead may have provided an advantage to competitor tree species. The fact that no post-harvest scarification or other forest-floor treatments were conducted on the treated stands may also have contributed to the unfavorable seedbed conditions. Scarification of the forest floor after a logging operation can be critical in removing surface litter and exposing mineral soil, both of which can enhance successful germination of lightseeded species such as the pines we studied (Reuling et al. 2019). Techniques such as mastication that involve shredding, chopping, or chipping of the slash have also been used in conifer systems in other places (Reiner et al. 2009), and can be explored in our study area.

\section{Seed source and overstory effects}

Although resources at the microsite level may be strongly impacted by factors such as competition and seedbed characteristics as discussed above, availability of adequate seed sources is also important. Residual trees on the harvested stands are likely to be the primary source of seeds for new colonization in mixed-pine stands, although some seeds may be dispersed from other sources (Carey 1993; Hauser 2008). We believe that the residual red pine and eastern white pine trees in our VRH stands can provide an adequate seed source for new recruitment based on visual assessment and the number of retained mature trees (basal area of $22 \mathrm{~m}^{2}$ per ha). Potentially supporting this assessment, a study in our region found that seed trees left after logging activities were associated with quicker regeneration and a more diverse growth structure in the post-disturbance regenerating population (Palik and Pregitzer 1994). Although seed supply would be a function of seed crop productivity (Ahlgren 1976; Hauser 2008), we do not think that lack of a seed source was a significant contributor to the low recruitment of red pine. Nevertheless, additional studies on seed crop dynamics of the two pines species in this study would likely shed more light on the quantity and viability of seeds produced by the residual trees.

The nature of the overstory composition and structure can also influence light, temperature, and moisture conditions in the understory (Oliver and Larson 1996). This VRH treatment targeted a $30 \%$ retention of the initial stand basal area in each of the two retention treatments. This retention level was selected as a middle ground between higher retention levels that may not adequately modify understory environmental conditions (Aubry et al. 2009), and lower retention levels that may create extreme changes, thereby giving competitor species an advantage (Peck et al. 2012; Reuling et al. 2019). Given an adequate seed source, coupled with its versatile characteristics (Abrams 2001), eastern white pine has been shown to have better recruitment even under a high overstory cover (Dovčiak et al. 2003). Comparatively, red pine is more shade intolerant with greater recruitment success in more open stands where there is greater light penetration reaching the forest floor (Hauser 2008). We cannot conclusively infer the impact of the $30 \%$ retention level on the observed recruitment patterns in this study as we did not have comparative tests of other retention levels. Given the silvical characteristics of the two pine species however, we think that this retention level provided adequate overstory conditions for their recruitment. We also believe that the previously described factors of competition and seedbed condition were greater drivers of recruitment in these stands compared to the impact of the level of retention.

\section{Spatial pattern of retention}

The two retention treatments (aggregated and dispersed) have been thought to have different effects on resource availability and plant competitive interactions (Boyden et al. 2012; Montgomery et al. 2013). By allowing for spatial variation in overstory structure and composition, the two retention patterns can provide contrasts in postharvest stand structure. This diversity of structures can provide opportunities for some ecological objectives to be met by dispersing retained structures and other 
objectives by aggregating them (Franklin et al. 2007; Halpern et al. 2012). Variations in spatial pattern of post-treatment structures can also provide heterogeneity in competitive environments across the stand, which can be targeted to favor recruitment of specific species (Boyden et al. 2012). Further, the retention patterns may provide opportunities to emulate patterns created on the landscape by different disturbance events or by varied intensities of such events (Franklin et al. 2007).

Literature suggests that red pine regeneration would be more successful in the aggregated retention while eastern white pine is likely to do well in both retention patterns (Palik and Zasada 2003). This difference has been attributed to the potential for greater changes in competitive environments in gaps created by the aggregated retention treatment, leading to favorable conditions for regeneration of pine species such as red pine that have more specific germination requirements (Battaglia et al. 2002; Palik and Zasada 2003). While we largely expected that the differences described above would hold for our study, we did not find consistent differences in the effects of VRH between the two retention treatments. Recruitment of red pine and eastern white pine did not differ significantly between the two retention treatments during both time periods as we had hypothesized.

These findings compare with those of other studies that have found no significant differences among retention patterns when survival, growth, and performance of planted red pine, eastern white pine, and jack pine seedlings were examined (Powers et al. 2011; Montgomery et al. 2013). Other studies have found differences among retention patterns with regards to growth of planted pine seedlings and resource availability (Palik et al. 2003; Boyden et al. 2012; Peck et al. 2012). We think that the relative impact of the two retention treatments in our study may have been moderated by the strong effect of competitor vegetation and the unfavorable seedbed conditions. These factors may have had a strong confounding effect, potentially masking differences in treatment effects between the retention patterns. It is also possible that there are just no marked differences in the responses of these two pine species between the aggregated and dispersed retention patterns when VRH is implemented at the $30 \%$ retention level. If the latter is the case, and depending on the scale and management objectives, such similarities in species responses between retention patterns may provide managers with the flexibility to accommodate multiple management objectives (Franklin et al. 2018), especially where such objectives are complimentary.

We would like to conclude our discussion by noting that this study examined natural regeneration of red pine and eastern white pine in response to VRH, with no pre-harvest site preparation treatments or seeding of the desired species. We also examined responses only up to six years since harvest, which is a relatively short successional timeframe for long-lived species such as red pine and eastern white pine. A longer-term study, with additional components that examines for example changes in the down woody debris or seed production by the retained mature trees could provide additional insights into other drivers of recruitment in these stands. We also note that VRH as a forest management practice has certain limitations that are often a function of the condition of the forest, the size of the management unit, the landscape context, and management objectives, as highlighted by Palik et al. (2020). They advise that before embarking on a VRH treatment, an assessment needs to be made as to whether the range of structures created by the retention treatments represents characteristics typical of the ecosystem following a natural disturbance. Also, because you are creating a matrix of varied structures within a given forest area (i.e., some trees removed and others retained in various patterns), a large management unit is likely to be more supportive of the practical and operational aspects of VRH compared to a smallersized unit. Finally, if the forest is managed for commercial timber production, the potential economic cost and priority tradeoffs needed to diversify structural and compositional features in the stand should be considered carefully when adopting VRH as a management practice.

\section{Conclusions}

Our findings indicate greater recruitment of both red pine and eastern white pine in VRH stands and significant increases in recruitment with time. Although both species increased significantly from year two to year six, red pine exhibited very low recruitment during the first two years while eastern white pine regeneration was higher in both years. We attribute the low red pine recruitment in the initial years to competition from sprouts of deciduous tree species, and unfavorable seedbed conditions. Eastern white pine on the other hand likely did better due to its less strict germination and establishment requirements, including seedbed conditions, competition, and shade tolerance. The lack of recruitment of red pine, decline in recruitment of eastern white pine with time, and significant increases in recruitment of deciduous trees with time in the unharvested stands all suggest a potential for significant alterations in species composition and stand structure beyond thresholds of recovery, in the absence of restoration interventions.

We hope that our findings contribute to expanding the application of VRH in similar forest types in the region and beyond. We believe that adoption and expansion of ecologically based silvicultural approaches is critical as we seek to enhance resilience and adaptive capacity of forest ecosystems across the globe so they 
can better survive the impacts of climate change and minimize their vulnerability. Finally, while the general concepts and principles of VRH are typically similar and hence replicable in similar ecosystem types, treatments are likely to be most effective when tailored to suit the specific ecosystem type and management objectives.

\section{Abbreviations}

CCA: Canonical Correspondence Analysis; SNWR: Seney National Wildlife Refuge; VRH: Variable retention harvesting

\section{Acknowledgements}

We are very grateful to all the interns who assisted with data collection, and the SNWR staff who supported our field activities throughout the study period.

\section{Authors' contributions}

Conceived and designed the study: PN, CG, GC and DH. Collected data: PN and field assistants. Wrote the paper: PN. Reviewed the paper: CG, GC and $\mathrm{DH}$. All authors read and approved the final manuscript.

\section{Funding}

This work was jointly supported by the Joint Fire Science Program (JFSP), The Ohio State University, Seney National Wildlife Refuge (SNWR), and Seney Natural History Association.

\section{Availability of data and materials}

The datasets used and/or analyzed during the current study are available from the corresponding author on reasonable request.

\section{Ethics approval and consent to participate}

Not applicable.

\section{Consent for publication}

Not applicable.

\section{Competing interests}

The authors declare that they have no competing interests.

\section{Author details}

'Natural Resources Management Program, Grand Valley State University, 1 Campus Dr, Allendale, Ml 49401, USA. ${ }^{2}$ Department of Forest, Rangeland, and Fire Sciences, University of Idaho, 875 Perimeter Drive MS 1133, Moscow, ID 83844, USA. ${ }^{3}$ Alpena-Montmorency Conservation District, 1900 M-32 W, Alpena, Ml 49707, USA. ${ }^{4}$ School of Environment and Natural Resources, The Ohio State University, 2021 Coffey Road, Columbus, OH 43210, USA.

Received: 6 March 2020 Accepted: 2 July 2020

Published online: 16 August 2020

\section{References}

Abrams M (1998) The red maple paradox. Bioscience 48(5):355-364

Abrams MD (2001) Eastern white pine versatility in the presettlement forest. Bioscience 51(11):967-979

Ahlgren CE (1976) Regeneration of red pine and white pine following wildfire and logging in northeastern Minnesota. J For 74(3):135-140

Ahlgren CE, Ahlgren IF (1981) Some effects of different forest litters on seed germination and growth. Can J For Res 11(3):710-714

Albert DA (1995) Regional landscape ecosystems of Michigan, Minnesota, and Wisconsin: a working map and classification. Gen. Tech. Rep. NC-178. USDA Forest Service North Central Forest Experiment Station, St. Paul, MN Aubry KB, Halpern CB, Peterson CE (2009) Variable-retention harvests in the Pacific Northwest: a review of short-term findings from the DEMO study. Forest Ecol Manag 258(4):398-408

Battaglia MA, Mou P, Palik BJ, Mitchell RJ (2002) The effect of spatially variable overstory on the understory light environment of an open-canopied longleaf pine forest. Can J For Res 32(11):1984-1991

Bebber DP, Cole WG, Thomas SC, Balsillie D, Duinkerc P (2005) Effects of retention harvests on structure of old-growth Pinus strobus $L$. stands in Ontario. Forest Ecol Manag 205:91-103
Beese WJ, Deal J, Dunsworth BG, Mitchell SJ, Philpott TJ (2019) Two decades of variable retention in British Columbia: a review of its implementation and effectiveness for biodiversity conservation. Ecol Process 8:33

Boyden S, Montgomery R, Reich PB, Palik B (2012) Seeing the forest for the heterogeneous trees: stand-scale resource distributions emerge from treescale structure. Ecol Appl 22(5):1578-1588

Burger TL, Kotar J (2003) A guide to forest communities and habitat types of Michigan. University of Wisconsin Press, Madison, p 400

Carey JH (1993) Pinus strobus. In: Fire effects information system. U.S. Department of Agriculture, Forest Service, Rocky Mountain Research Station, Fire Sciences Laboratory (producer). http://www.fs.fed.us/database/feis/. Accessed 15 Jan 2020

Cleland DT, Crow TR, Saunders SC, Dickmann DI, Maclean AL, Jordan JK, Watson RL, Sloan AM, Brosofske KD (2004) Characterizing historical and modern fire regimes in Michigan (USA): a landscape ecosystem approach. Landsc Ecol 19: $311-325$

Corace RG III, Shartell LM, Goebel PC, Kashian DM, Drobyshev I, Hix DM (2014) Bird communities of reference and altered mixed-pine forests: implications for restoring fire-dependent forest ecosystems. Forest Ecol Manag 318:183193

Corace RG III, Stout AT, Goebel PC, Hix DM (2013) Snag benchmarks and treatment options for mixed-pine forest restoration in eastern upper Michigan. Restor Ecol 21(5):608-616

D'Amato AW, Segari J, Gilmore D (2012) Influence of site preparation on natural regeneration and understory plant communities within red pine shelterwood systems. North J Appl For 29(2):60-66

Dietrich R, Gore S, Hossain SMY, Anand M (2017) Over and understory controls on red pine establishment and seedling survival in the largest remaining oldgrowth red pine forest. Forest Ecol Manag 385:57-64

Dovčiak M, Reich PB, Frelich LE (2003) Seed rain, safe sites, competing vegetation, and soil resources spatially structure white pine regeneration and recruitment. Can J For Res 33(10):1892-1904

Drobyshev I, Goebel PC, Hix DM, Corace RG III, Semko-Duncan ME (2008a) Preand post-European settlement fire history of red pine dominated forest ecosystems of Seney National Wildlife Refuge, Upper Michigan. Can J For Res 38:2497-2514

Drobyshev I, Goebel PC, Hix DM, Corace RG III, Semko-Duncan ME (2008b) Interactions among forest composition, structure, fuel loadings and fire history: a case study of red pine-dominated forests of Seney National Wildlife Refuge, Upper Michigan. Forest Ecol Manag 256:1723-1733

Fedrowitz K, Koricheva J, Baker SC, Lindenmayer DB, Palik B, Rosenvald R, Beese W, Franklin JF, Kouki J, Macdonald E, Messier C, Sverdrup-Thygeson A, Gustafsson L (2014) Can retention forestry help conserve biodiversity? A meta-analysis. J Appl Ecol 51:1669-1679

Fei S, Steiner KC (2009) Rapid capture of growing space by red maple. Can J For Res 39:1444-1452

Franklin CMA, Macdonald SE, Nielsen SE (2018) Combining aggregated and dispersed tree retention harvesting for conservation of vascular plant communities. Ecol Appl 28:1830-1840

Franklin JF, Donato DC (2020) Variable retention harvesting in the Douglas-fir region. Ecol Process 9:8

Franklin JF, Mitchell RJ, Palik BJ (2007) Natural disturbance and stand development principles for ecological forestry. Gen. Tech. Rep. NRS-19. USDA Forest Service Northern Research Station, Newtown Square, PA

Frelich LE (1995) Old forest in the Lake States today and before European settlement. Nat Areas J 15(2):157-167

Godman RM, Mattson GA (1976) Seed crops and regeneration of 19 species in northeastern Wisconsin. USDA Forest Service, Research Paper NC-123. North Central Forest Experiment Station, St. Paul, p 5

Gustafsson L, Baker SC, Bauhus J, Beese WJ, Brodie A, Kouki J, Lindenmayer DB, Lõhmus A, Pastur GM, Messier C, Neyland M, Palik B, Sverdrup-Thygeson A, Volney WJA, Wayne A, Franklin JF (2012) Retention forestry to maintain multifunctional forests: a world perspective. Bioscience 62:633-645

Halpern CB, Halaj J, Evans SA, Dovčiak M (2012) Level and pattern of overstory retention interact to shape long-term responses of understories to timber harvest. Ecol Appl 22:2049-2064

Halpern CB, McKenzie D (2001) Disturbance and post-harvest ground conditions in a structural retention experiment. Forest Ecol Manag 154:215-225

Halpern CB, McKenzie D, Evans SA, Maguire DA (2005) Initial responses of forest understories to varying levels and patterns of green-tree retention. Ecol Appl 15:175-195 
Hauser AS (2008) Pinus resinosa. In: Fire effects information system. U.S. Department of Agriculture, Forest Service, Rocky Mountain Research Station, Fire Sciences Laboratory (Producer). http://www.fs.fed.us/database/feis/. Accessed 19 Jan 2020

Helms JA (1998) The dictionary of forestry. Society of American Foresters, Bethesda

Landhäusser SM (2009) Impact of slash removal, drag scarification, and mounding on lodgepole pine cone distribution and seedling regeneration after cut-to-length harvesting on high elevation sites. Forest Ecol Manag 258: 43-49

Lindenmayer D, Blair D, McBurney L (2019) Variable retention harvesting in Victoria's Mountain Ash (Eucalyptus regnans) forests (southeastern Australia). Ecol Process 8:2

Lindenmayer DB, Franklin JF (2002) Conserving forest biodiversity: a comprehensive multiscaled approach. Island Press, Washington DC

Lindenmayer DB, Franklin JF, Lõhmus A, Baker SC, Bauhus J, Beese W, Brodie A, Kiehl B, Kouki J, Martinez-Pastur G, Messier C, Neyland M, Palik B, SverdrupThygeson A, Volney J, Wayne A, Gustafsson L (2012) A major shift to the retention approach for forestry can help resolve some global sustainability issues. Conserv Lett 5:421-431

Mallik AU (2003) Conifer regeneration problems in boreal and temperate forests with ericaceous understory: role of disturbance, seedbed limitation, and keystone species change. Crit Rev Plant Sci 22:341-366

Mallik AU, Roberts BA (1994) Natural regeneration of Pinus resinosa on burned and unburned sites in Newfoundland. J Veg Sci 5(2):179-186

Midwestern Regional Climate Center (MRCC) (2020) The Midwestern Regional Climate Center. NCDC and the Illinois State Water Survey, Champaign http:// mcc.sws.uiuc.edu/index.jsp. Accessed 12 Jan 2020

Montgomery RA, Palik BJ, Boyden SB, Reich PB (2013) New cohort growth and survival in variable retention harvests of a pine ecosystem in Minnesota, USA. Forest Ecol Manag 310:327-335

Mori AS, Kitagawa R (2014) Retention forestry as a major paradigm for safeguarding forest biodiversity in productive landscapes: a global metaanalysis. Biol Conserv 175:65-73

Nagel LM, Palik BJ, Battaglia MA, D'Amato AW, Guldin JM, Swanston CW, Janowiak MK, Powers MP, Joyce LA, Millar Cl, Peterson DL, Ganio LM, Kirschbaum C, Roske MR (2017) Adaptive silviculture for climate change: a national experiment in manager-scientist partnerships to apply an adaptation framework. J For 115:167-178

Nyamai PA, Goebel PC, Hix DM, Corace RG III, Drobyshev I (2014) Fire history, fuels, and overstory effects on the regeneration-layer dynamics of mixedpine forest ecosystems of eastern Upper Michigan, USA. Forest Ecol Manag 322:37-47

Oliver CD, Larson BC (1996) Forest stand dynamics. Wiley, New York City

Palik BJ, D'Amato AW (2019) Variable retention harvesting in Great Lakes mixedpine forests: emulating a natural model in managed ecosystems. Ecol Process 8(1):16

Palik BJ, D'Amato AW, Franklin JF, Johnson KN (2020) Ecological silviculture foundations and applications. Waveland Press, Inc., Long Grove

Palik BJ, Pregitzer KS (1994) White pine seed-tree legacies in an aspen landscape: influences on post-disturbance white pine population structure. Forest Ecol Manag 67:191-201

Palik BJ, Zasada JC (2003) An ecological context for regenerating multi-cohort, mixed-species red pine forests. Research Note NC-382. USDA Forest Service North Central Research Station, St. Paul

Palik BJ, Zasada JC, Kern CC (2003) Restoring stand complexity in managed red pine (Pinus resinosa) ecosystems using overstory retention and understory control. Establishment report and revised study plan. Northern Great Lakes Silviculture Research Work Unit, NCRS, USDA Forest Service, Grand Rapids

Peck JE, Zenner EK, Palik BJ (2012) Variation in microclimate and early growth of planted pines under dispersed and aggregated overstory retention in mature managed red pine in Minnesota. Can J For Res 42:279-290

Powers MD, Pregitzer KS, Palik BJ (2008) Physiological performance of three pine species provides evidence for gap partitioning. Forest Ecol Manag 256:21272135

Powers MD, Pregitzer KS, Palik BJ, Webster CR (2011) The physiological basis for regeneration response to variable retention harvest treatments in three pine species. Forestry 84:13-22

Puettmann K, Coates KD, Messier CC (2009) A critique of silviculture: managing for complexity. Island Press, Washington, DC
Puettmann KJ, Wilson SM, Baker SC, Donoso PJ, Drössler L, Amente G, Harvey BD, Knoke T, Lu Y, Nocentini S, Putz FE, Yoshida T, Bauhus J (2015) Silvicultural alternatives to conventional even-aged forest management - what limits global adoption? Forest Ecosyst 2:8

Reiner AL, Vaillant NM, Fites-Kaufman J, Dailey SN (2009) Mastication and prescribed fire impacts on fuels in a 25-year old ponderosa pine plantation, southern Sierra Nevada. Forest Ecol Manag 258:2365-2372

Reuling LF, D'Amato AW, Palik BJ, Martin KJ, Fassnacht DS (2019) Initial tree regeneration response to natural-disturbance-based silviculture in secondgrowth northern hardwood forests. Can J For Res 49:628-639

Roberts MW, D'Amato AW, Kern CC, Palik BJ (2016) Long-term impacts of variable retention harvesting on ground-layer plant communities in Pinus resinosa forests. J Appl Ecol 53:1106-1116

Roberts MW, D'Amato AW, Kern CC, Palik BJ (2017) Effects of variable retention harvesting on natural tree regeneration in Pinus resinosa (red pine) forests. Forest Ecol Manag 385:104-115

Scott RE, Neyland MG, Baker SC (2019) Variable retention in Tasmania, Australia: trends over 16 years of monitoring and adaptive management. Ecol Process $8: 23$

Seymour RS, White AS, deMaynadier PG (2002) Natural disturbance regimes in northeastern North America_evaluating silvicultural systems using natural scales and frequencies. Forest Ecol Manag 155:357-367

USDA NRCS (2014) The PLANTS database. National Plant Data Team, Greensboro http://plants.usda.gov. Accessed Apr 132014

Weyenberg SA, Frelich LE, Reich PB (2004) Logging versus fire: how does disturbance type influence the abundance of Pinus strobus regeneration? Silva Fenn 38:179-194

Whitney GG (1987) An ecological history of the Great Lakes forest of Michigan. J Ecol 75:667-684

Wiensczyk A, Swift K, Morneault A, Thiffault N, Szuba K, Bell FW (2011) An overview of the efficacy of vegetation management alternatives for conifer regeneration in boreal forests. Forest Chron 87:175-200

\section{Submit your manuscript to a SpringerOpen ${ }^{\circ}$ journal and benefit from:}

- Convenient online submission

- Rigorous peer review

- Open access: articles freely available online

High visibility within the field

- Retaining the copyright to your article

Submit your next manuscript at $>$ springeropen.com 